\title{
HLA-DP-unrestricted TNF- $\alpha$ release in beryllium-stimulated peripheral blood mononuclear cells
}

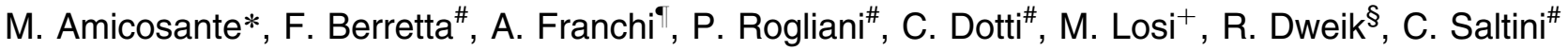

HLA-DP-unrestricted $T N F-\alpha$ release in beryllium-stimulated peripheral blood mononuclear cells. M. Amicosante, F. Berretta, A. Franchi, P. Rogliani, C. Dotti, M. Losi, R. Dweik, C. Saltini. (C)ERS Journals Ltd 2002.

ABSTRACT: Berylliosis is a granulomatous disorder of the lung caused by inhalation of beryllium (Be) and dominated by the accumulation of CD4+ T-helper (Th)1 memory $T$-cells proliferating in response to $B e$ in the lower respiratory tract. Two gene markers have been associated with susceptibility to berylliosis: 1) the human leucocyte antigen (HLA)-DP gene whose allelic variants, carrying glutamate in position 69 of the $\beta$-chain (HLA-DPGlu69), can bind Be directly and present it to interferon (IFN)- $\gamma$ releasing Th1 T-cell clones from patients with berylliosis; and 2) the cytokine gene tumour necrosis factor (TNF)- $\alpha$ which has been shown to increase berylliosis risk independent of HLA-DPGlu69.

In order to determine whether TNF- $\alpha$ release was triggered by $\mathrm{Th1} T$-cell activation by Be stimulation in the context of HLA-DPGlu69 molecules, the proliferation of $\mathrm{BeSO}_{4}$-stimulated blood mononuclear cells and the release of IFN- $\gamma$, TNF- $\alpha$, RANTES (regulated on activation normal T-cell expressed and secreted), granulocyte-macrophage colony-stimulating factor, interleukin (IL)-4, IL-6, IL-8, IL-10 and IL-12 by $\mathrm{BeSO}_{4^{-}}$ stimulated blood mononuclear cells was quantified in 11 individuals with berylliosis using an anti-HLA-DP antibody as a probe for HLA-DP restricted T-cell activation.

While proliferation and IFN- $\gamma$ release were completely abrogated by HLA-DP inhibition (inhibition with anti-HLA-DP monoclonal antibody (mAb): $88 \pm 16$ and $77 \pm 16 \%$, respectively; anti-HLA-DR: $29 \pm 38$ and $14 \pm 10 \%$, respectively), the release of TNF- $\alpha$ was not (inhibition with anti-HLA-DP mAb: $8.9 \pm 7.8 \%$ ). No other cytokine was detected at significant levels. Moreover, Be was able to induce TNF- $\alpha$ production in healthy control subjects not exposed to $\mathrm{Be}$ in the absence of $\mathrm{T}$-cell proliferation and IFN- $\gamma$ production.

In conclusion, these data suggest that the tumour necrosis factor- $\alpha$ response of mononuclear cells is independent of the activation of beryllium-specific human leucocyte anitgen-DP restricted T-cells, which is consistent with the finding that the tumour necrosis factorA2 and the human leucocyte anitgen-DPGlu69 genetic markers are independently interacting in increasing berylliosis risk.

Eur Respir J 2002; 20: 1174-1178.
*Laboratory of Clinical Pathology, and ${ }^{\#}$ Division of Respiratory Diseases of the University of "Tor Vergata", National Institute for Infectious Diseases (L. Spallanzani, IRCCS), Rome, Division of Occupational Medicine, Policlinico, Modena, and ${ }^{+}$Division of Pulmonary Medicine, Policlinico, Modena, Italy. ${ }^{\S}$ Pulmonary and Intensive Care Medicine, Cleveland Clinic Foundation, Cleveland, $\mathrm{OH}$, USA.

Correspondence: M. Amicosante, Laboratory of Clinical Pathology, INMI L. Spallanzani-IRCCS, Via Portuense 292, I-00149, Rome, Italy.

Fax: 39065582237

E-mail: amicosante@inmi.it

\section{Keywords: Berylliosis}

cytokines

human leukocyte antigen-DPGlu69

interferon- $\gamma$

T-cell proliferation

tumour necrosis factor- $\alpha$

\section{Received: November 162001}

Accepted after revision: June 122002

This study was supported by grants from US Dept of Energy (DoE) grant DE-FG02-93ER61714 and grant 99060855594 from MIUR, Italy.
Berylliosis is a chronic granulomatous disorder of the lung caused by inhalation of beryllium (Be) dusts affecting $1-16 \%$ of Be-exposed individuals $[1,2]$. The immunopathology of this disorder is dominated by the accumulation of $\mathrm{CD} 4+\mathrm{CD} 45 \mathrm{RO}+\mathrm{T}$-helper (Th)-1 memory T-cells proliferating in response to $\mathrm{Be}$ in the lower respiratory tract [3-5]. Previously, the current authors have shown that allelic variants of the human leucocyte antigen (HLA)-DP molecule carrying a glutamate residue in position 69 of the HLA-DP $\beta$-chain (HLA-DPGlu69) [6-8] play a central role in disease pathogenesis by directly binding $\mathrm{Be}$ in the absence of antigen processing [9] and by restricting the response to $\mathrm{Be}$ of $\mathrm{Th} 1 \mathrm{~T}$-cell clones derived from patients with berylliosis [10]. In addition, the current authors have shown that the tumour necrosis factor (TNF)A2 allele of the cytokine gene TNF- $\alpha$, which is expressed at exaggerated levels by lung and blood mononuclear cells from berylliosis patients in response to $\mathrm{Be}[11,12]$, is also associated with susceptibility to berylliosis and positively interacts with the HLA-DPGlu69 marker to increase berylliosis risk [13].

Since the Th1 cytokines interferon (IFN) $-\gamma$ and $\mathrm{TNF}-\alpha$, both hyperexpressed by berylliosis patient mononuclear cells in response to Be [12], play a central role in granulomatous reactions [14], one may question whether the expression of TNF- $\alpha$ is the consequence of Be-specific CD4 T-cell activation or is a related but independent event, as the genetic association finding may suggest.

To answer this question, blood mononuclear cells were obtained from individuals with berylliosis and both T-cells and mononuclear phagocytes were stimulated with $\mathrm{Be}$ using an anti-HLA-DP monoclonal antibody $(\mathrm{mAb})$ to separate the response to the metal of Be-specific HLA-DPGlu69-restricted Th1 CD4+ T-cells from that of the mononuclear phagocytes. 
Interestingly, consistent with the finding that the TNFA2 and HLA-DPGlu69 genetic markers are independently interacting in increasing berylliosis risk, the data indicate that the TNF- $\alpha$ response of the mononuclear phagocytes is independent of the activation of Be-specific HLA-DP restricted T-cells.

\section{Methods}

\section{Study population}

Eleven individuals with berylliosis were enrolled in the study after giving informed consent: 10 males and one female, all Caucasians, mean age $45 \pm 7$ yrs and average time of employment $15 \pm 6$ yrs. The study protocol was approved by the Cleveland Clinic IRB (Cleveland, OH, USA). As a control, five healthy nonBe-exposed individuals were enrolled: four males and one female, all Caucasians and mean age $32 \pm 3$ yrs.

\section{Lymphocyte proliferation}

Peripheral blood mononuclear cells (PBMCs) obtained from patients with berylliosis were isolated from heparinised whole blood by density centrifugation on a Ficoll Hypaque gradient. PBMCs $(2 \times$ $10^{5}$ cells $^{*}$ well $^{-1}$ ) were then cultured in 96-well flatbottomed microtitre plates in Roswell Park Memorial Institute (RPMI) 1640 tissue culture medium supplemented with $2 \mathrm{mM}$ L-glutamine, $10 \%$ foetal bovine serum, $100 \mathrm{U} \cdot \mathrm{mL}^{-1}$ penicillin, and $100 \mu \mathrm{g} \cdot \mathrm{mL}^{-1}$ streptomycin in the presence of beryllium sulfate $\left(\mathrm{BeSO}_{4}\left[4 \mathrm{H}_{2} \mathrm{O}\right]\right)$ at 10,50 and $100 \mu \mathrm{M}$ (all reagents form Sigma Co., St. Louis, MO, USA). Phytohaemoagglutinin (PHA; $5 \mu \mathrm{g} \cdot \mathrm{mL}^{-1}$; Sigma) and Candida albicans $\left(10 \mu \mathrm{g} \cdot \mathrm{mL}^{-1}\right)$ were used as positive controls. T-lymphocyte proliferation was measured by thrytiated deossiribonucleotide thymidine $\left(\left[{ }^{3} \mathrm{H}\right] \mathrm{TdR}\right)$ incorporation. After 5 days of culture, cells were pulsed with $1 \mu \mathrm{Ci}$ of $\left[{ }^{3} \mathrm{H}\right] \mathrm{TdR}$ (Amersham International, Amersham, UK) and harvested onto glassfibre filters $18 \mathrm{~h}$ later. Proliferation was measured as $\left[{ }^{3} \mathrm{H}\right]-\mathrm{TdR}$ incorporation by liquid scintillation spectroscopy. The results are expressed as the mean of triplicate cultures. The stimulation index was calculated as the ratio of mean counts per minute (cpm), in antigen-stimulated wells, to the mean cpm in control wells.

In order to evaluate possible contamination with the bacterial endotoxin product of the $\mathrm{BeSO}_{4}$ solution used as antigen, the $\mathrm{BeSO}_{4}$ batch solution used throughout the study was tested with the Limulus Amebocyte Lysate test (CAPE CODE Inc., Woods Hole, MA, USA). The stock solution of $\mathrm{BeSO}_{4}$ $(0.2 \mathrm{M})$ showed undetectable levels of endotoxin contamination $\left(<0.03 \mathrm{U} \cdot \mathrm{mL}^{-1}\right.$ of Escherichia coli endotoxin, similar to endotoxin-free water). Similarly, undetectable endotoxin levels were revealed for $\mathrm{BeSO}_{4}$ at the working concentration in RPMI complete medium.

\section{Measurement of cytokines in supernatants}

The levels of IFN- $\gamma$, TNF- $\alpha$, RANTES (regulated on activation normal T-cell expressed and secreted), granulocyte-macrophage colony-stimulating factor (GM-CSF), interleukin (IL)-4, IL-6, IL-8, IL-10 and IL-12 release in the culture supernatants of Be-stimulated PBMCs were evaluated with commercially available solid-phase, two-site enzymelinked immunosorbent assays (CytElisa; CytImmune Science, San Diego, CA, USA). Cell supernatants were collected after 3 days (RANTES, GM-CSF, IL-4 and IL-12) and 5 days (IFN- $\gamma$, TNF- $\alpha$, IL-6, IL-8 and IL-10) of PBMC culture before $\left[{ }^{3} \mathrm{H}\right] \mathrm{TdR}$ incorporation, and frozen at $-80^{\circ} \mathrm{C}$ until use. Cytokine concentrations were evaluated in triplicate and the results expressed as the mean of triplicate cultures.

\section{Monoclonal antibody inhibition of lymphocyte activation}

Protein-A sepharose purified $\mathrm{mAb}$ directed against HLA-DR (L243) [10], HLA-DP (B7/21) [10], HLADQ (L2) [10], HLA-class I (W6/32) [10] and the $19 \mathrm{kDa}$ Mycobacterium tuberculosis protein (HYT6) [15] were used at increasing concentrations (10, 20 and $50 \mu \mathrm{g} \cdot \mathrm{mL}^{-1}$ ) to inhibit antigen presentation, lymphocyte proliferation and cytokine production as previously described [5].

\section{HLA typing}

HLA-DP and TNFA1/A2 typing was carried out as previously described [13].

\section{Statistical analysis}

All the data were expressed as mean \pm sD. Comparisons between groups were made with t-tests. Comparisons between frequencies were made using the Chi-squared test with the Yates and Bonferroni corrections where necessary.

\section{Results}

\section{$H L A-D P$ restriction of beryllium-stimulated lymphocyte proliferation}

All PBMCs obtained from berylliosis patients $(n=11)$, carrying glutamate-69-positive HLA-DP alleles, showed positive responses to PHA and the recall antigen $C$. albicans (table 1). Of these, nine had a proliferative response to $\mathrm{BeSO}_{4}$ that was $>3$ times the mean SI of unstimulated cells (table 1). In all cells the antiHLA-DP specific $\mathrm{mAb}$ induced a marked inhibition of Be-stimulated proliferation $(88 \pm 16 \%)$ that was significantly greater than that obtained with $\mathrm{mAbs}$ against HLA-DR $(29 \pm 38 \%)$, HLA-DQ $(2 \pm 2 \%)$, class-I major histocompatability complex (MHC; $1 \pm 2 \%$ ), and 
Table 1.-Mitogen (phytohaemogglutinin (PHA))-, Candida albicans- and beryllium $\left(\mathrm{BeSO}_{4}\right)$-induced proliferation and cytokine release in fresh peripheral blood mononuclear cells from berylliosis patients

\begin{tabular}{lccccc}
\hline & Subjects $\mathrm{n}$ & Cells only & + PHA & + C. albicans & $+\mathrm{BeSO}_{4}$ \\
\hline Proliferation SI & 11 & & $120.6 \pm 105.2^{*}(11)$ & $26.2 \pm 21.5^{*}(11)$ & $8.9 \pm 9.8^{*}(9)$ \\
IFN- $\gamma \mathrm{U} \cdot \mathrm{mL}^{-1}$ & 10 & $27.9 \pm 12.8$ & $858.4 \pm 994.0^{*}(10)$ & $626.2 \pm 662.1^{*}(10)$ & $163.6 \pm 83.3^{*}(9)$ \\
TNF- $\alpha \mathrm{pg} \cdot \mathrm{mL}^{-1}$ & 9 & $111.8 \pm 26.4$ & $1149.6 \pm 740.9^{*}(9)$ & $750.1 \pm 426.6^{*}(9)$ & $290.7 \pm 95.6^{*}(7)$ \\
RANTES pg $\cdot \mathrm{mL}^{-1}$ & 5 & $774 \pm 186$ & $3718 \pm 2671^{*}(5)$ & & $1280 \pm 673(1)$ \\
GM-CSF pg$\cdot \mathrm{mL}^{-1}$ & 5 & $149.6 \pm 98.2$ & $874.2 \pm 445.9^{*}(5)$ & $489.3 \pm 155.2(3)$ & $220.6 \pm 128.6(0)$ \\
IL-4 $\mathrm{pg} \cdot \mathrm{mL}^{-1}$ & 5 & $7.2 \pm 3.7$ & $27.8 \pm 9.7^{*}(5)$ & & $7.4 \pm 2.3(0)$ \\
IL-6 pg $\cdot \mathrm{mL}^{-1}$ & 5 & $6.8 \pm 5.2$ & $36.2 \pm 5.1^{*}(5)$ & & $9.8 \pm 6.3(0)$ \\
IL-8 $\mathrm{pg} \cdot \mathrm{mL}^{-1}$ & 5 & $10550 \pm 9086$ & $131522 \pm 27928^{*}(5)$ & & $18180 \pm 11333(0)$ \\
IL-10 $\mathrm{pg} \cdot \mathrm{mL}^{-1}$ & 5 & $0.8 \pm 1.3$ & $230.8 \pm 123.9^{*}(5)$ & $23.0 \pm 41.4(2)$ & $1.0 \pm 1.7(0)$ \\
IL-12 $\mathrm{pg} \cdot \mathrm{mL}^{-1}$ & 5 & $21.8 \pm 34.5$ & $359.0 \pm 190.1^{*}(5)$ & $159.3 \pm 167.1^{*}(3)$ & $17.4 \pm 34.6(0)$ \\
\hline
\end{tabular}

Data are presented as mean \pm SD ( $\mathrm{n}^{\#}$ of positive tests). IFN: interferon; TNF: tumour necrosis factor; RANTES: regulated on activation normal T-cell expressed and secreted; GM-CSF: granulocyte-macrophage colony-stimulating factor; IL: interleukin. \#: number of subjects showing a proliferative response $\geqslant 3$-fold the mean background incorporation of unstimulated cells or a cytokine release $\geqslant 3$ SD above the mean background release by unstimulated cells. $*: p<0.05$, paired t-test compared to unstimulated cells.

the M. tuberculosis $19 \mathrm{kDa}$-specific protein $(0 \pm 1 \%$; $\mathrm{p}<0.05$ for all comparisons with anti-HLA-DP; fig. 1).

Finally, PBMCs from Be-non-exposed healthy subjects did not proliferate in response to $\mathrm{BeSO}_{4}$ (data not shown).

\section{$H L A-D P$ restriction of interferon- $\gamma$}

beryllium-stimulated release by mononuclear cells

PBMCs from all 10 patients tested released IFN- $\gamma$ in response to PHA and $C$. albicans (table 1). Bestimulated IFN- $\gamma$ release was significantly higher than control in nine of 10 patients (table 1 ). The release of this cytokine was strongly blocked by the anti-HLADP mAb $(77 \pm 16 \%)$ but not by the other mAbs used (anti-HLA-DR, $14 \pm 10 \%$; anti-HLA-DQ, $1 \pm 2 \%$; anticlass-I, $1 \pm 1 \%$; anti- $M$. tuberculosis $19 \mathrm{kDa}$-specific protein, $0 \pm 1 \% ; \mathrm{p}<0.05$ for all comparisons with antiHLA-DP; fig. 1).

Finally, none of the five healthy non-Be-exposed controls released IFN- $\gamma$ in response to $\mathrm{BeSO}_{4}$ (data not shown).
Lack of HLA-DP restriction of tumour necrosis factor- $\alpha$ beryllium-stimulated release by mononuclear cells

PBMCs from all of the nine berylliosis patients tested released $\mathrm{TNF}-\alpha$ in response to PHA and C. albicans (750.1 \pm 426.6$)$. PBMCs from seven of the subjects evaluated also released $\mathrm{TNF}-\alpha$ in response to $\mathrm{Be}$ stimulation at levels that were significantly higher than controls (table 1). However, in contrast to IFN- $\gamma$, the release of TNF- $\alpha$ was not blocked by the anti-HLA-DP specific mAb (fig. 1). Similarly to berylliosis patients, PBMCs obtained from four of five non-Be-exposed healthy subjects released TNF- $\alpha$ in response to $\mathrm{BeSO}_{4}\left(195.3 \pm 76.2 \mathrm{pg} \cdot \mathrm{mL}^{-1}, \mathrm{p}=0.02\right.$ with respect to Be-unstimulated PBMCs (91.9 \pm 15.8 ); $\mathrm{p}=0.09$ with respect to $\mathrm{PBMCs}$ from berylliosis patients stimulated with $\mathrm{BeSO}_{4}$ ), while anti-HLA class II monoclonal antibodies had no effect on the cytokine release (data not shown).

No significant levels of the cytokines IL-4, IL-6, IL-8, IL-10, IL-12, GM-CSF and RANTES were found in Be-stimulated culture supernatants of
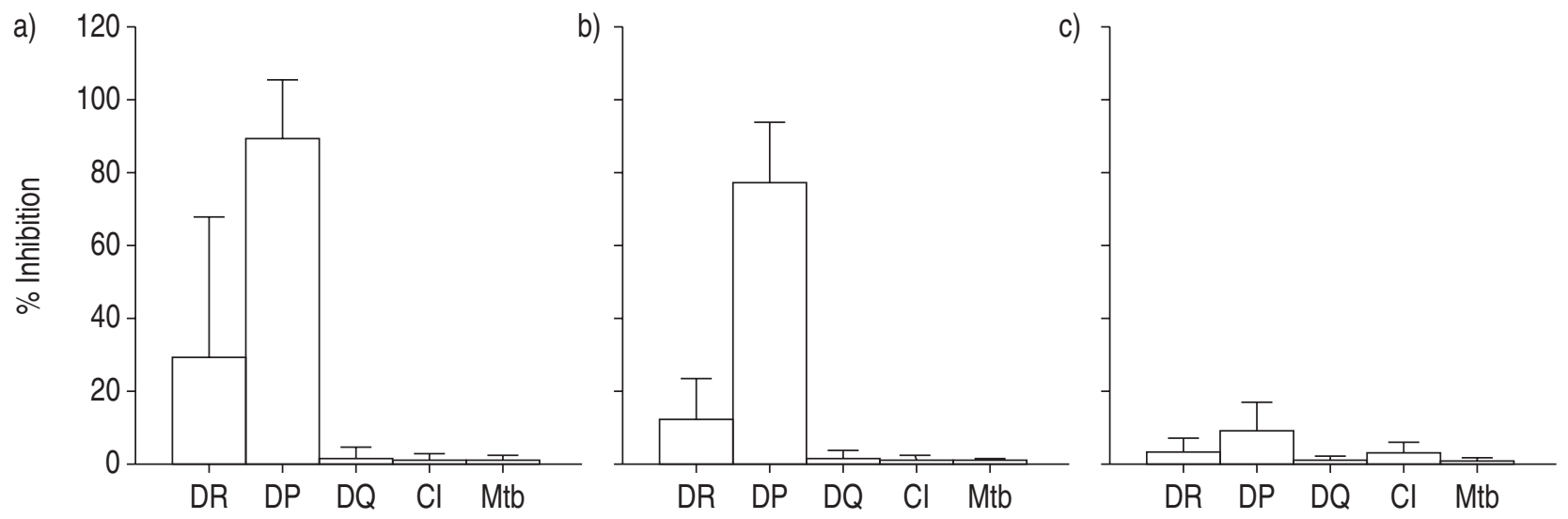

Fig. 1. - Inhibition of beryllium-induced a) proliferation, b) interferon- $\gamma$ and c) tumour necrosis factor- $\alpha$ release by monoclonal antibodies directed against human leucocyte antigen (HLA)-DR, HLA-DP, HLA-DQ, HLA-class I and the $19 \mathrm{kDa}$ Mycobacterium tuberculosis protein in peripheral blood mononuclear cells from berylliosis patients. DR: anti-HLA-DR; DP: anti-HLA-DP; DQ: anti-HLA-DQ; CI: anti-HLA-class I; Mtb: anti-19 kDa M. tuberculosis. 
PBMCs from any of the patients tested, although all cytokines were released in response to PHA stimulation (table 1). Finally, when $\mathrm{TNF}-\alpha$ release levels were analysed in relation to the carriage of the TNFA2 allele (TNFA2/TNFA1 or TNFA2/TNFA2) and those who carried only the TNFA1 allele, no differences were found either in the response to $\mathrm{Be}$ (TNFA2-negative, $\mathrm{n}=5,281 \pm 90 \mathrm{pg} \cdot \mathrm{mL}^{-1}$; TNFA2positive, $\left.\mathrm{n}=4, \quad 312 \pm 108 \mathrm{pg} \cdot \mathrm{mL}^{-1} ; \mathrm{p}>0.05\right)$ or to PHA (TNFA2-negative, $1,232 \pm 778 \mathrm{pg} \cdot \mathrm{mL}^{-1}$; TNFA2positive, $\left.1,385 \pm 761 \mathrm{pg} \cdot \mathrm{mL}^{-1} ; \mathrm{p}>0.05\right)$ and $C$. albicans (TNFA2-negative, $741 \pm 469 \mathrm{pg} \cdot \mathrm{mL}^{-1}$; TNFA2-positive, $\left.633 \pm 546 \mathrm{pg} \cdot \mathrm{mL}^{-1} ; \mathrm{p}>0.05\right)$.

\section{Discussion}

Studies previously carried out by this and other groups [6-8] have suggested that the HLA-DP- $\beta$ chain allelic variant coding for a glutamate residue in position 69 is the immune response gene associated with $\mathrm{Be}$ binding and the induction of the Th1 lymphocyte response that characterises berylliosis [9-11, 16, 17]. In addition, consistent with the observation that TNF- $\alpha$ is released at exaggerated rates in the lungs of individuals with berylliosis [18], the current authors have shown that the TNF- $\alpha$ gene allelic variant TNFA2, implicated in the regulation of TNF- $\alpha$ release [19], is also associated with susceptibility to berylliosis, positively interacting with the HLA-DPGlu69 marker in the determination of berylliosis risk [13].

In granulomatous disorders, such as tuberculosis, leprosy and sarcoidosis, IFN- $\gamma$-producing Th1 T-cells dominate the disease immune response [20-23]. The observation that proliferation and IFN $-\gamma$ release by fresh blood mononuclear cells in response to $\mathrm{Be}$ are completely abrogated by the anti-HLA-DP specific $\mathrm{mAb}$ suggests that in berylliosis-affected individuals the Th1 response to $\mathrm{Be}$ is systemic. The fact that HLA-DP glutamate 69-positive molecules are capable of directly binding $\mathrm{Be}$ [9], may suggest that $\mathrm{Be}$ presentation in the presence of this molecule may itself drive the Th1 response, as has been described in animal models where the Th1 or Th2 polarisation of the immune response is dictated by a specific $\mathrm{MHC} /$ peptide combination [24].

TNF- $\alpha$, together with IFN-y, is the dominant cytokine produced in the reaction to $\mathrm{Be}$ by mononuclear cells from berylliosis patients. Since TNF- $\alpha$ is primarily released by mononuclear phagocytes [25], it is reasonable to question whether cytokine production is driven by, or independent of, Th1 T-cell activation and IFN- $\gamma$ release. The antibody blocking experiments presented here clearly show that Bestimulated blood mononuclear phagocytes were able to release TNF- $\alpha$ independently of HLA-DP restricted IFN- $\gamma$ release. Moreover, the ability of PBMCs from non-Be-exposed healthy subjects to release TNF- $\alpha$ in response to Be strongly support this notion.

Finally, the current authors were unable to demonstrate a correlation between TNF- $\alpha$ levels in Be-stimulated cultures and the TNFA1/TNFA2 genotypes. However, although it has been proposed that
TNF- $\alpha$ release is under the control of a polymorphic sequence with two known alleles (TNFA1 and TNFA2), whereby TNFA2 is associated with higher PHA/phorbol myristate acetate-stimulated cytokine release [19], not all studies have confirmed this finding $[26,27]$.

The cell function data in this study further support the concept that the tumour necrosis factor- $\alpha$ and human leucocyte antigen-DP genes are immunogenetic independent factors of berylliosis and that they may interact in the development of the granulomatous reaction induced by beryllium in the lung.

\section{References}

1. Saltini C, Markham TN, Jones Williams W. Berylliosis. The Granulomatous Disorders. London, Cambridge University Press, 1999; pp. 336-351.

2. Kreiss K, Wasserman S, Mroz MM, Newman LS. Beryllium disease screening in the ceramics industry. Blood lymphocyte test performance and exposuredisease relations. Occup Med 1993; 35: 267-274.

3. Epstein PE, Dauber JH, Rossman MD, Daniele RP. Bronchoalveolar lavage in a patient with chronic berylliosis: evidence for hypersensitivity pneumonitis. Ann Intern Med 1982; 97: 213-216.

4. Rossman MD, Kern JA, Elais JA, et al. Proliferative response of bronchoalveolar lymphocytes to beryllium. Ann Intern Med 1988; 108: 687-693.

5. Saltini C, Winestock K, Kirby M, Pinkston P, Crystal RG. Maintenance of alveolitis in patients with chronic beryllium disease by beryllium-specific helper $\mathrm{T}$ cells. $N$ Engl J Med 1989; 320: 1103-1109.

6. Richeldi L, Sorrentino R, Saltini C. HLA-DPB1 glutamate 69: a genetic marker of beryllium disease. Science 1993; 262: 242-244.

7. Wang Z, White PS, Petrovic M, et al. Differential susceptibilities to chronic beryllium disease contributed by different Glu69 HLA-DPB1 and -DPA1 alleles. J Immunol 1999; 163: 1647-1653.

8. Richeldi L, Kreiss K, Mroz MM, Zhen B, Tartoni P, Saltini C. Interaction of genetic and exposure factors in the prevalence of berylliosis. Am J Ind Med 1997; 32: $337-340$.

9. Amicosante $\mathrm{M}$, Sanarico $\mathrm{N}$, Berretta $\mathrm{F}$, et al. Beryllium binding to HLA-DP molecule carrying the marker of susceptibility to berylliosis glutamate 369. Hum Immunol 2001; 62: 686-693.

10. Lombardi G, Germain C, Uren J, et al. DP allelespecific $\mathrm{T}$ cell responses to beryllium account for DPassociated susceptibility to chronic beryllium disease. J Immunol 2001; 166: 3549-3555.

11. Tinkle SS, Schwitters PW, Newman LS. Cytokine production by bronchoalveolar lavage cells in chronic beryllium disease. Environ Health Perspect 1996; 104: Suppl. 5, 969-971. 
12. Tinkle SS, Kittle LA, Schwitters BA, Addison PW Jr, Newman LS. Beryllium stimulates release of $T$ helper 1 cytokines IL-2 and IFN- $\gamma$ from BAL cells in chronic beryllium disease. J Immunol 1997; 158: 518-526.

13. Saltini C, Richeldi L, Losi M, et al. Major histocompatibility locus (MHC) genetic markers of beryllium sensitization and disease. Eur Respir J 2001; 18: 677-684.

14. Romagnani S. Biology of human TH1 and TH2 cells. J Clin Immunol 1995; 15: 121-129.

15. Khanolkar-Young S, Kolk AH, Andersen AB, et al. Results of the third immunology of leprosy/immunology of tuberculosis antimycobacterial monoclonal antibody workshop. Infect Immun 1992; 60: 3925-3927.

16. Fontenot AP, Torres M, Marshall WH, Newman LS, Kotzin BL. Beryllium presentation to CD4+ $\mathrm{T}$ cells underlies disease-susceptibility HLA-DP alleles in chronic beryllium disease. Proc Natl Acad Sci USA 2000; 97: 12717-12722.

17. Fontenot AP, Falta MT, Freed BM, Newman LS, Kotzin BL. Identification of pathogenic $\mathrm{T}$ cells in patients with beryllium-induced lung disease. J Immunol 1999; 163: 1019-1026.

18. Bost TW, Riches DW, Schumacher B, et al. Alveolar macrophages from patients with beryllium disease and sarcoidosis express increased levels of mRNA for tumor necrosis factor- $\alpha$ and interleukin- 6 but not interleukin-1ß. Am J Respir Cell Mol Biol 1994; 10: $506-513$.

19. Higuchi T, Seki N, Kamizono S, et al. Polymorphism of the $5^{\prime}$-flanking region of the human tumor necrosis factor (TNF)-alpha gene in Japanese. Tissue Antigens 1998; 51: 605-612.
20. Zhang M, Lin Y, Iyer DV, Gong J, Abrams JS, Barnes PF. T-cell cytokine responses in human infection with Mycobacterium tuberculosis. Infect Immun 1995; 63: 3231-3234.

21. Modlin RL, Melamcon-Kaplan J, Young SMM, et al. Learning from lesions: patterns of tissue inflammation in leprosy. Proc Natl Acad Sci USA 1988; 85: 12131217.

22. Bergeron A, Bonay $\mathrm{M}$, Kambouchner $\mathrm{M}$, et al. Cytokine patterns in tuberculous and sarcoid granulomas: correlations with histopathologic features of the granulomatous response. J Immunol 1997; 159: 3034-3043.

23. Manca F, Rossi G, Valle MT, et al. Limited clonal heterogeneity of antigen-specific $\mathrm{T}$ cells localizing in the pleural space during mycobacterial infection. Infect Immun 1991; 59: 503-513.

24. Murray JS. How the MHC selects Th1/Th2 immunity. Immunol Today 1998; 19: 157-163.

25. Beutler B, Cerami A. The biology of cachectin/TNF- $\alpha$ primary mediator of the host response. Ann Rev Immunol 1989; 7: 625-635.

26. Uglialoro AM, Turbay $\mathrm{D}$, Pesavento OA, et al. Identification of three new single nucleotide polymorphisms in the human tumor necrosis factor-a gene promoter. Tissue Antigens 1998; 52: 359-367.

27. Skoog T, van't Hooft FM, Kallin B, et al. A common functional polymorphism (C-A substitution at position -863) in the promoter region of the tumour necrosis factor-alpha (TNF-alpha) gene associated with reduced circulating levels of TNF-alpha. Hum Mol Genet 1999; 8: 1443-1449. 